\title{
Temporal coherence among tropical coastal lagoons: a search for patterns and mechanisms
}

\author{
Caliman, A. ${ }^{\mathrm{a}, \mathrm{c}}$, Carneiro, $L S .^{\mathrm{a}, \mathrm{c}}$, Santangelo, JM. ${ }^{\mathrm{a}, \mathrm{d}}$, Guariento, RD. ${ }^{\mathrm{a}}$, Pires, APF. ${ }^{\mathrm{a}}$, Suhett, AL. ${ }^{\mathrm{a}}$,

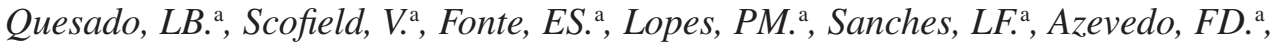 \\ Marinho, CC. ${ }^{\mathrm{a}}$, Bozelli, RL. ${ }^{\mathrm{a}}$, Esteves, FA. ${ }^{\mathrm{a}, \mathrm{b}}$ and Farjalla, VF. ${ }^{\mathrm{a}, \mathrm{b} *}$
}
a'Departamento de Ecologia, Instituto de Biologia, Prédio do CCS, Universidade Federal do Rio de Janeiro - UFRJ Ilha do Fundão, CP 68020, CEP 21941-590, Rio de Janeiro, RJ, Brazil
'Núcleo em Ecologia e Desenvolvimento Sócio-Ambiental de Macaé - NUPEM,

Universidade Federal do Rio de Janeiro - UFRJ, Av. Rotary Club, s/n, São José do Barreto, CP 119331, Macaé, RJ, Brazil

'Departamento de Botânica, Ecologia e Zoologia, Universidade Federal do Rio Grande do Norte - UFRN, CEP 59072-970, Natal, RN, Brazil
dDepartamento de Ciências Ambientais, Instituto de Florestas, Universidade Federal Rural do Rio de Janeiro - UFRRJ, Rod. BR 465, Km 07, CEP 23890-000, Seropédica, RJ, Brazil.
*e-mail: farjalla@biologia.ufrj.br

Received January 8, 2010 - Accepted June 5, 2010 - Distributed October 31, 2010

(With 6 figures)

\begin{abstract}
Temporal coherence (i.e., the degree of synchronicity of a given variable among ecological units within a predefined space) has been shown for several limnological features among temperate lakes, allowing predictions about the structure and function of ecosystems. However, there is little evidence of temporal coherence among tropical aquatic systems, where the climatic variability among seasons is less pronounced. Here, we used data from long-term monitoring of physical, chemical and biological variables to test the degree of temporal coherence among 18 tropical coastal lagoons. The water temperature and chlorophyll- $a$ concentration had the highest and lowest temporal coherence among the lagoons, respectively, whereas the salinity and water colour had intermediate temporal coherence. The regional climactic factors were the main factors responsible for the coherence patterns in the water temperature and water colour, whereas the landscape position and morphometric characteristics explained much of the variation of the salinity and water colour among the lagoons. These results indicate that both local (lagoon morphometry) and regional (precipitation, air temperature) factors regulate the physical and chemical conditions of coastal lagoons by adjusting the terrestrial and marine subsidies at a landscape-scale. On the other hand, the chlorophyll- $a$ concentration appears to be primarily regulated by specific local conditions resulting in a weak temporal coherence among the ecosystems. We concluded that temporal coherence in tropical ecosystems is possible, at least for some environmental features, and should be evaluated for other tropical ecosystems. Our results also reinforce that aquatic ecosystems should be studied more broadly to accomplish a full understanding of their structure and function.
\end{abstract}

Keywords: synchrony, temporal coherence, local factors, regional factors, shallow lakes, coastal lagoons.

\section{Coerência temporal entre lagoas costeiras tropicais: uma busca por padrões e mecanismos}

\section{Resumo}

A coerência temporal (i.e., o nível de sincronismo de uma dada variável ecológica entre unidades ecológicas) tem sido demonstrada para uma vasta gama de variáveis limnológicas em lagos de clima temperado, permitindo que predições sobre a estrutura e o funcionamento destes ecossistemas sejam realizadas. Entretanto, há pouca evidência da coerência temporal de variáveis limnológicas entre ecossistemas aquáticos tropicais, onde a variação climática é menos pronunciada entre as estações do ano. Neste estudo, utilizamos dados de longa duração do monitoramento de variáveis físicas, químicas e biológicas para testar a ocorrência de coerência temporal entre 18 lagoas costeiras tropicais. A temperatura da água e a concentração de clorofila- $a$ apresentaram, respectivamente, a maior e a menor coerência temporal entre as lagoas, enquanto que a salinidade e a coloração da água apresentaram padrões intermediários. Fatores climáticos regionais foram os principais fatores responsáveis pelos padrões de coerência da temperatura e coloração da água, enquanto que a orientação em relação ao mar e as características morfométricas das lagoas explicaram boa 
parte da variação da salinidade e da coloração da água entre as lagoas. Estes resultados indicam que tanto fatores locais (morfometria) quanto regionais (precipitação, temperatura do ar) regulam as condições físicas e químicas das lagoas costeiras pela contribuição dos ecossistemas terrestre e marinho em uma escala da paisagem. Por outro lado, a concentração de clorofila- $a$ é aparentemente limitada por condições locais específicas, resultando em um fraco padrão de coerência temporal entre as lagoas. Concluímos que a coerência temporal em ecossistemas tropicais é possível, pelo menos para algumas variáveis ambientais, e deve ser avaliada para outros ecossistemas. Nossos resultados também reforçam a ideia que ecossistemas aquáticos devem ser estudados em uma perspectiva mais ampla (e.g. de bacia de drenagem) para o completo entendimento da sua estrutura e funcionamento.

Palavras-chave: sincronismo, coerência temporal, fatores locais, fatores regionais, lagos rasos, lagoas costeiras.

\section{Introduction}

The properties of aquatic ecosystems have recently been considered in the context of landscapes, where lakes in a geographic area are examined to identify common and long-term behaviour patterns for one or more variables (Carpenter et al., 2007; Das et al., 2009; Magnuson et al., 1990; Soranno et al., 1999). As a result, limnologists have increasingly considered lakes to be dynamic ecological units connected and organized across the landscape, rather than spatially independent entities (Baines et al., 2000; Kratz et al., 1991; Webster et al., 2000). Because lake behaviour is a product of both extrinsic forces and intrinsic processes, determining the relative importance of these drivers is fundamental to the understanding of the dynamics and function of a lake (Stoddard et al., 1998).

Determining the temporal coherence among lakes is an important approach to identify the degree to which lake properties correspond to regional broad-scale forces rather than to more local, in-lake forces (George et al., 2000; Magnuson et al., 1990). It is defined as the degree to which the temporal series of environmental features (biotic and/ or abiotic) obtained in a subset of aquatic environments within a predefined space are positively correlated (i.e., vary synchronously). Extrinsic forces, such as climate or episodic disturbances operating over broad spatial scales, can promote synchronous behaviour in a suite of system variables (Blenckner et al., 2007; Das et al., 2009), while internal forces, such as differences in the lake size and morphometry, and species composition and food-source, often lead to a more idiosyncratic temporal behaviour, indicating the predominance of local-scale regulators (Webster et al., 2000; Kent et al., 2007; Weyhenmeyer 2008; Lansac-Toha et al., 2008; Takahashi et al., 2008).

Previous studies have demonstrated that temporal coherence varies greatly with the climate, the number of processes affecting the dynamics of a variable and the sensitivity of a variable to locally unique conditions (Kratz et al., 2003). In general, physical variables such as the water surface temperature are strongly coherent over large distances among different lakes (Livingstone and Dokulil, 2001). Water chemistry has also been shown to be temporally coherent for a myriad of variables (Folster et al., 2005), although to a lesser extent than the physical properties because dissolved ions and substances are also greatly affected by lake size, morphometry and landscape position
(Kratz et al., 1991). Biological variables, on the other hand, are less coherent than most physical variables and chemical compounds (Lansac-Toha et al., 2008; Takahashi et al., 2008). From an ecosystem management perspective, identifying temporal coherence among lakes is paramount to a reliable extrapolation of results obtained from a set of sites to results for a larger region, and to monitor the regional effects of broad-scale environmental variations predicted by global change scenarios (Stoddard et al., 1998; Arnott et al., 2003).

Most of the studies regarding temporal coherence of lakes have been carried out in temperate regions, primarily in North America and Europe (see Blenckner et al., 2007; Folster et al., 2005; Kratz et al., 2003 and references therein). These regions are subjected to great inter-seasonal temperature variation, which might have an overwhelming influence over lake temporal dynamics, resulting in the high degree of temporal coherence demonstrated in such studies. The extent to which temporal coherence is a pervasive ecological phenomenon among tropical lakes, where climatic conditions are more constant over the year, remains elusive. In this context, tropical coastal lagoons are interesting model systems to test the occurrence of temporal coherence. A great number of coastal lagoons might occur within a relatively small area, which guarantees a greater similarity in their respective exposition to broad-scale regional factors such as climate, surrounding edaphic conditions and sea proximity. On the other hand, coastal lagoons are physiographically diversified systems, ranging in a variety of sizes, morphometries, water chemistry characteristics, landscape positions and trophic status (reviewed in Esteves et al., 2008). For instance, hypersaline and freshwater lagoons can be found side-by-side depending on the relative strength of the particular drivers of their hydrological balance, such as local precipitation, watershed inflow, evaporation and intrusion of seawater by percolation through or overtop the sand barrier (Kjerfve, 1994). The concentrations of coloured dissolved organic carbon have also been reported to be highly variable among closely located coastal lagoons (Farjalla et al., 2002), suggesting that there is a strong local control of the input of terrestrial carbon subsidies in these systems. On the other hand, the input rates of terrestrial organic matter and carbon mineralisation in a specific lagoon were demonstrated to be 
seasonally regulated by the precipitation level, indicating that climate is an important extrinsic factor affecting coastal lagoon dynamics (Suhett et al., 2007).

In the present study, we tested the occurrence of temporal coherence in a suite of physical, chemical and biological variables over a group of South Atlantic coastal lagoons that encompass a vast array of local characteristics. Our primary expectations were that (1) temporal coherence is stronger for physical and chemical variables than for biotic variables, and that (2) temporal coherence is dictated by both local traits (such as lagoon morphometry and landscape position), and regional climate (such as solar irradiation and precipitation).

\section{Material and Methods}

\subsection{Study area}

This study was performed in 18 coastal lagoons situated in the northern region of the state of Rio de Janeiro, Brazil $\left(22^{\circ}-22^{\circ} 30^{\prime} \mathrm{S}\right.$ and $41^{\circ} 15^{\prime}-42^{\circ} \mathrm{W}$ - Figure 1$)$. All but one lagoon (Imboassica lagoon) are situated at the Restinga de Jurubatiba National Park, a mosaic landscape of 14,860 ha composed of shrub vegetations, flooded forest patches and coastal lagoons on the Atlantic coastal plain. The Imboassica lagoon is also located on a coastal plain, but urban areas occupy its surroundings and directly dispose of untreated sewage into it. The natural surrounding vegetation of the Imboassica lagoon has been practically removed. All 18 lagoons are nontidal permanently closed off systems; variations in salinity are mainly attributed to seawater intrusions that overtop the lagoon's sand barrier during sea storms. However, some human-caused disruptions of the sand bar that separates each lagoon from the ocean have been observed during the summer, particularly for the Imboassica lagoon. All lagoons are shallow (0.5-4.0 m), and variations in the perimeter and area have been observed (Table 1). Substantial natural differences in the limnological features, particularly in the concentrations of salt, nutrients and chlorophyll- $a$, and in the water colour, have been observed among these lagoons throughout history (Tables 1 and 2). The monitoring protocol of these lagoons has been inserted into the Brazilian Long-Term-Ecological-Research Program (PELD-LTER - Site 5), which aims to evaluate the chemical, physical and biological characteristics of these ecosystems in relation to natural and anthropogenic disturbances (Rocha, CFD. et al., 2004). The climate of the region is characterised as tropical sub-humid/humid with a mean summer temperature of $25^{\circ} \mathrm{C}$, an average

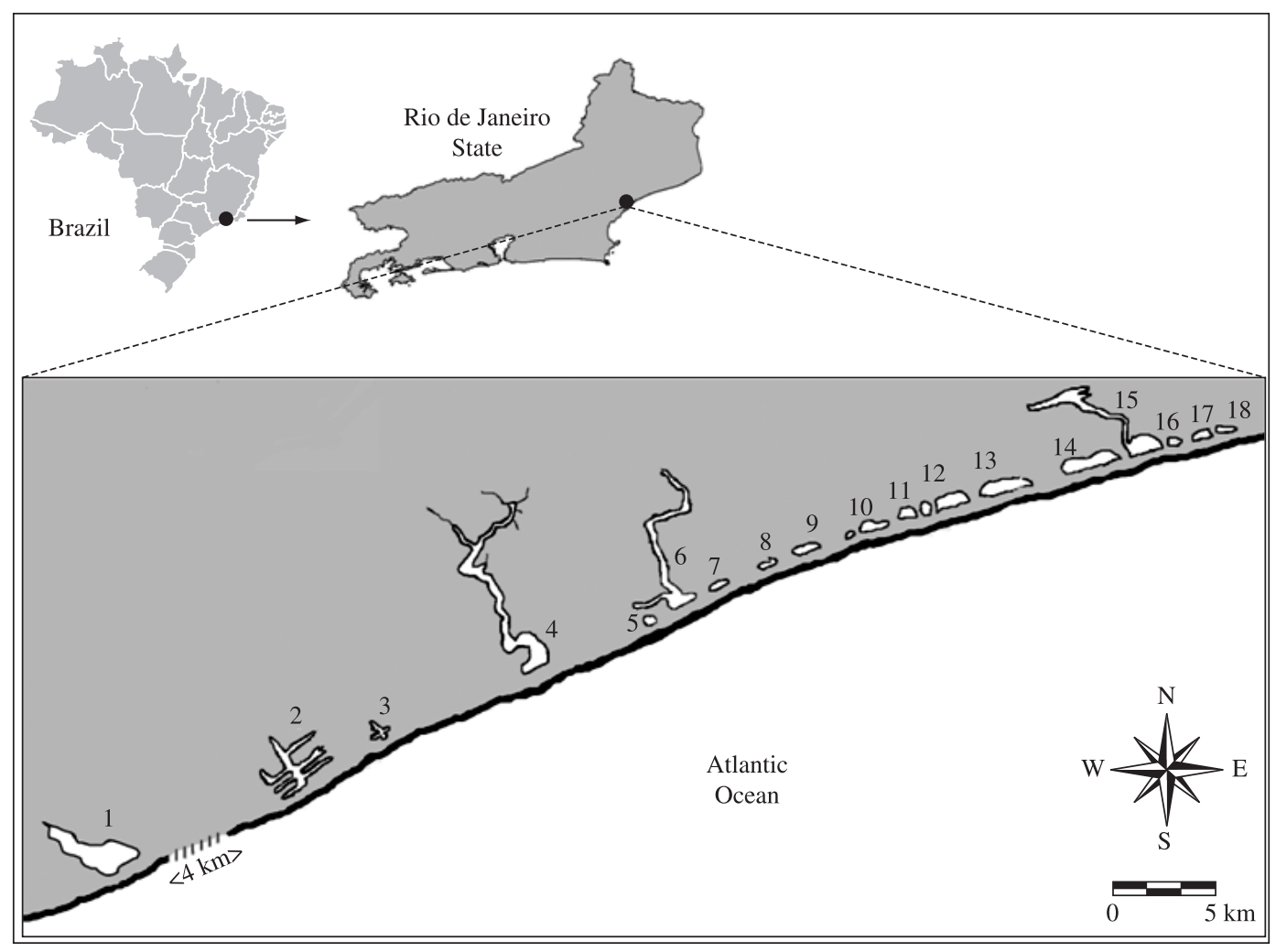

Figure 1. Map illustrating the geographical position as well as the physiographic differences of the 18 studied coastal lagoons. The coastal lagoons are numbered as follows: 1) Imboassica, 2) Cabiúnas, 3) Comprida, 4) Carapebus, 5) Encantada, 6) Paulista, 7) Amarra Boi, 8) Bezerra, 9) Garças, 10) Maria Menina, 11) Robalo, 12) Visgueiro, 13) Catingosa, 14) Pires, 15) Preta, 16) Barrinha, 17) Casa Velha, 18) Ubatuba. 
Table 1. Data of the variables used in the temporal coherence analysis (area, perimeter, salinity, chlorophyll- $a$ concentration, water temperature, water colour and landscape position). Mean \pm SD. * Lagoons sampled monthly between 2002-08. Other lagoons were sampled semi-annually between 2004-08.

\begin{tabular}{|c|c|c|c|c|c|c|c|c|}
\hline Lagoon & $\begin{array}{l}\text { Area } \\
\left(\mathbf{k m}^{2}\right)\end{array}$ & $\begin{array}{l}\text { Perimeter } \\
\quad(\mathbf{k m})\end{array}$ & $\begin{array}{l}\text { Perimeter: } \\
\text { area ratio }\end{array}$ & Salinity & $\begin{array}{l}\text { Chlorophyll- } a \\
\left(\mu \mathrm{g} . \mathbf{L}^{-1}\right)\end{array}$ & $\begin{array}{c}\text { Water } \\
\text { temperature } \\
\left({ }^{\circ} \mathrm{C}\right)\end{array}$ & $\begin{array}{c}\text { Water } \\
\text { colour } \\
(\text { Abs } 430 \mathrm{~nm})\end{array}$ & $\begin{array}{c}\text { Landscape } \\
\text { position }\end{array}$ \\
\hline Imboassica* & 2.60 & 12.49 & 4.81 & $3.52 \pm 4.22$ & $18.43 \pm 20.22$ & $25.27 \pm 2.54$ & $0.02 \pm 0.02$ & Orthogonal \\
\hline Cabiúnas* & 0.34 & 14.61 & 42.67 & $1.01 \pm 1.60$ & $3.42 \pm 3.92$ & $25.54 \pm 2.62$ & $0.04 \pm 0.02$ & Orthogonal \\
\hline Comprida* & 0.11 & 3.61 & 31.75 & $0.13 \pm 0.06$ & $3.71 \pm 4.19$ & $25.35 \pm 2.66$ & $0.11 \pm 0.06$ & Orthogonal \\
\hline Carapebus* & 4.11 & 42.52 & 10.34 & $5.31 \pm 3.72$ & $5.35 \pm 6.19$ & $25.86 \pm 2.57$ & $0.03 \pm 0.03$ & Orthogonal \\
\hline Encantada & 0.05 & 1.24 & 24.95 & $5.16 \pm 6.38$ & $5.37 \pm 4.50$ & - & - & Parallel \\
\hline Paulista & 1.41 & 25.65 & 18.23 & $2.27 \pm 1.75$ & $4.06 \pm 4.43$ & - & - & Orthogonal \\
\hline Amarra Boi & 0.22 & 2.56 & 11.82 & $0.27 \pm 0.40$ & $14.97 \pm 15.38$ & - & - & Parallel \\
\hline Bezerra & 0.02 & 0.86 & 53.25 & $1.71 \pm 2.42$ & $14.33 \pm 21.62$ & - & - & Parallel \\
\hline Garças* & 0.21 & 2.87 & 13.55 & $31.22 \pm 28.75$ & $10.98 \pm 10.42$ & $25.15 \pm 2.71$ & $0.06 \pm 0.13$ & Parallel \\
\hline Maria Menina & 0.60 & 4.32 & 7.16 & $15.31 \pm 9.42$ & $26.52 \pm 24.19$ & - & - & Parallel \\
\hline Robalo & 1.25 & 8.97 & 7.18 & $25.05 \pm 12.68$ & $19.45 \pm 13.23$ & - & - & Parallel \\
\hline Visgueiro & 1.21 & 5.43 & 4.49 & $28.41 \pm 21.70$ & $11.49 \pm 8.62$ & - & - & Parallel \\
\hline Catingosa & 0.09 & 1.36 & 15.58 & $25.31 \pm 21.37$ & $30.56 \pm 30.43$ & - & - & Parallel \\
\hline Pires & 1.59 & 6.73 & 4.22 & $17.39 \pm 24.48$ & $12.25 \pm 18.22$ & - & - & Parallel \\
\hline Preta & 1.94 & 20.66 & 10.63 & $7.51 \pm 9.61$ & $7.12 \pm 13.80$ & - & - & Orthogonal \\
\hline Barrinha & 0.28 & 2.32 & 8.29 & $11.40 \pm 15.92$ & $12.25 \pm 12.97$ & - & - & Parallel \\
\hline Casa Velha & 0.53 & 5.13 & 9.69 & $8.98 \pm 9.11$ & $19.13 \pm 18.30$ & - & - & Parallel \\
\hline Ubatuba & 0.34 & 3.45 & 10.14 & $7.99 \pm 5.89$ & $30.66 \pm 30.18$ & - & - & Parallel \\
\hline
\end{tabular}

Table 2. Minimum, mean, standard deviation (SD) and maximum values for some limnological features of coastal lagoons.

\begin{tabular}{|c|c|c|c|}
\hline $\begin{array}{c}\text { Limnological } \\
\text { variable } \\
\end{array}$ & Minimum & Mean \pm SD & Maximum \\
\hline Depth (m) & 0.5 & $0.82 \pm 0.31$ & 3.00 \\
\hline $\mathrm{pH}$ & 3.17 & $7.21 \pm 1.20$ & 9.39 \\
\hline Salinity (ppt) & 0 & $15.55 \pm 13.35$ & 160 \\
\hline $\begin{array}{l}\text { Total } \\
\text { phosphorus }(\mu \mathrm{M})\end{array}$ & 0.12 & $2.87 \pm 2.48$ & 28.47 \\
\hline $\begin{array}{l}\text { Total nitrogen } \\
(\mu \mathrm{M})\end{array}$ & 18.74 & $100.65 \pm 35.70$ & 244.58 \\
\hline $\begin{array}{l}\text { Chlorophyll- } a \\
\left(\mu \mathrm{g} . \mathrm{L}^{-1}\right)\end{array}$ & 0.02 & $15.68 \pm 8.88$ & 79.71 \\
\hline
\end{tabular}

winter temperature of about $19{ }^{\circ} \mathrm{C}$, and an annual mean relative humidity of $83 \%$ (Rocha, AM. et al., 2004). The annual precipitation is $1,165 \mathrm{~mm}$ and there is a pronounced seasonal distribution with minimum precipitation occurring in June $(40 \mathrm{~mm})$ and maximum precipitation occurring in December (190 mm) (Berg et al., 2004).

\subsection{Samplings and analytical methods}

Two different samplings were performed. The first sampling was performed semi-annually (dry and wet seasons) in all 18 lagoons when the salinity and chlorophyll- $a$ concentration (Chl- $a$ ) were evaluated. This sampling lasted from February 2004 to August 2008. The second sampling was performed monthly in 5 lagoons (Imboassica, Cabiúnas, Comprida, Carapebus and Garças lagoons) from January 2002 to December 2008 and the water temperature and colour, salinity and Chl- $a$ were evaluated. We chose these variables 1) based on their importance as descriptors of biotic and abiotic aspects of the functioning or coastal lagoons; 2) in order to increase the power of statistical analysis as we had a considerable amount of data of these variables for the monitored lagoons and 3) because these variables do not change significantly throughout the day, but are sensitive in response to regional environmental drivers, such as climate and sea storms (Enrich-Prast et al., 2004). In addition, we carried out all samplings in a same geographic location (station) in a given lagoon, and all samplings were conducted during the mornings and never exceeded 6 hours, assuring the homogeneity of environmental conditions in a sampling day. Finally, samplings were systematically performed from east to west (see Figure 1).

The water temperature and salinity were directly determined using a portable thermo-salinometer multifunctional probe (YSI Model 30/10 FT). For the determination of the Chl- $a$ and water colour, water samples were collected in acid-rinsed polyethylene flasks and transported to the field laboratory. The water temperature was kept constant during the transport and the analyses were performed up to $6 \mathrm{~h}$ after samplings. The samples were filtered in glass-fibre filters ( $\varnothing=47 \mathrm{~mm}, \sim 1.2 \mu \mathrm{m}$ pore size, GF/C Whatman), and the water colour was determined in the filtered water 
sample by light absorption at $430 \mathrm{~nm}$ in $1 \mathrm{~cm}$-cuvette (Strome and Miller, 1978). The filters were stored in the dark at $4{ }^{\circ} \mathrm{C}$ for Chl- $a$ analysis. The Chl- $a$ was extracted with $90 \%$ ethanol and the concentration was determined by spectrophotometry at $665 \mathrm{~nm}$ (Nush and Palme, 1975). Both of the photometrical analyses were performed in a Beckman ${ }^{\circ}$ DU520 spectrophotometer. Finally, we calculated some morphometrical characteristics of these lagoons. The perimeter and area of each lagoon, as well as the length of the main axis, were calculated using the ArcGIS software version 9.2 after satellite images were acquired from Google Earth 5.

\subsection{Data analysis}

We first measured the temporal coherence of each variable by calculating the pair-to-pair correlation coefficients between the lagoons using the GraphPad Prism 5.0 software for Windows. A Kolmogorov-Smirnov's test was used to test the normality of each variable, and whenever necessary, the variables were transformed, standardised and centred to meet specific test assumptions. Irrespective to data transformation, the Chl- $a$ data in both samplings and the salinity data in semi-annually sampling did not present normal distribution. Therefore, Pearson's correlation was used for the water temperature, water colour and salinity data from the monthly sampling, while the non-parametric Spearman rank correlation was used for the salinity data from the semi-annually sampling and for the Chl- $a$ data from both samplings. The degree of the temporal coherence was assumed to be the magnitude of the correlation coefficient, and only significant correlations $(p<0.05)$ were interpreted to be true synchronous behaviour between any two lagoons. Moreover, several assumptions were tested in order to use the time series correlations as an indicator of temporal coherence. First, a randomised lake time series yielded correlations that were centred on zero, supporting a standard null model expectation. Pearson and Spearman correlations generated similar results in all of the cases, irrespective of the data distribution. Finally, excluding the maximum values from the time series did not significantly alter correlations among the lake pairs.

To avoid that punctual anthropogenic interferences (i.e. artificial sand bar opening) in the Imboassica lagoon affect the ability of our analysis to detect temporal coherent patterns, all pairwise correlations regarding this lagoon were just performed using data sampled after 4 months of the last sand bar opening. This period is sufficient to allow the reestablishment of biotic and abiotic lagoons characteristics before sand bar breaching (Enrich-Prast et al., 2004).

We calculated the mean and the standard deviation of the correlation values to compare the degree of temporal coherence among the variables. Moreover, we correlated some of the morphometrical characteristics of lagoons to some of the temporal coherence estimates. First, we classified the lagoons in relation to their landscape position as "parallel-oriented" when the lagoon's major axis was parallel to the sea, and "orthogonally-oriented" when the lagoon's major axis was orthogonal to the sea. Then, we compared the mean correlation values for the salinity between the pairs of lagoons at a similar landscape position (parallel-oriented vs. parallel-oriented or orthogonallyoriented vs. orthogonally-oriented) with pairs of lagoons at a dissimilar landscape position (parallel-oriented vs. orthogonally-oriented), using a $t$-test. For this analysis, only the salinity was used because the spatial configuration mainly influences the susceptibility of a lagoon to ocean intrusions (Enrich-Prast et al., 2004). Each pair of lagoons was also characterised by how they differ with respect to the ratio of perimeter to area (Table 1), by taking the Euclidian distance of this ratio for each pair of lagoons $(\Delta)$. The $\Delta$ perimeter: area ratio was used to estimate the differences of lakes in their susceptibility to the surrounding terrestrial ecosystem, which drives, for instance, the entrance of allochthonous humic carbon and consequently, water colour (Farjalla et al., 2009). Linear regressions were performed to evaluate if different $\Delta s$ were related to mean correlation values of the water colour. Only positive and significant correlation values were used in these analyses.

Finally, a linear mixed model was used to analyse the possible seasonal changes in the water colour of different lagoons. Because precipitation events are more frequent and stronger in the summer than in other seasons, we divided the monthly water colour data by a function of the season (summer months = rainy season, other months = dry season). These seasons were considered to be categorical predictors, and the accumulated precipitation in each season was considered as a co-variable, the lagoons and the sampling year were treated as sampling blocks, and the water colour was considered as the response variable. This analysis was performed using the library (nlme) in the R-statistical package 2.10.0 (R Development Core Team, 2009).

\section{Results}

After considering the semi-annual sampling for all of the lagoons, we found that the salinity was strongly and positively correlated between a set of the lagoons, composed of the Bezerra, Maria Menina, Robalo, Visgueiro, Catingosa, Pires, Preta, Barrinha and Casa Velha lagoons $\left(r_{\text {Spearman }}>0.81\right.$ in most of the cases, Figure 2a). Some additional lagoons also had positive correlations of their salinity values, specifically: Cabiúnas with Paulista $\left(r_{\text {Spearman }}=0.86\right)$, with Encantada $\left(r_{\text {Spearman }}=0.72\right)$ and with Carapebus $\left(r_{\text {Spearman }}=0.63\right)$; Paulista with Encantada $\left(r_{\text {Spearman }}=0.80\right)$; and Garças with Pires $\left(r_{\text {Spearman }}=0.64\right)$, with Catingosa $\left(r_{\text {Spearman }}=0.67\right)$ and with Bezerra $\left(r_{\text {Spearman }}=0.70\right)$ (Figure 2a). On the other hand, the salinity was negatively correlated between the following pairs of lagoons: Preta with Cabiúnas $\left(r_{\text {Spearman }}=-0.68\right)$, with Carapebus $\left(r_{\text {Spearman }}=-0.73\right)$ and with Amarra-Boi $\left(r_{\text {Spearman }}=-0.68\right)$; Paulista with Ubatuba $\left(r_{\text {Spearman }}=-0.66\right)$; and Visgueiro with Carapebus $\left(r_{\text {Spearman }}=-0.69\right)$ (Figure 2a). The mean Spearman correlation coefficient $\left(r_{\text {Spearman }}\right)$ for the salinity within this data set was $0.21(\mathrm{SD}=0.52$, Figure $2 \mathrm{a})$. Considering the positive correlations (synchronous lagoons), the $r_{\text {Spearman }}$ values for the salinity were higher for the pairs of lagoons at similar landscape positions than for pairs of lagoons at different landscape positions ( $t$-test, $\mathrm{F}=4.384$, $\mathrm{df}=106, \mathrm{p}<0.0001$, Figure 3 ). 
Significant correlations among the 18 lagoons were much less frequent regarding the Chl- $a$ (Figure 2b). Positive correlations were found between Ubatuba and Encantada $\left(r_{\text {Spearman }}=0.72\right)$, Garças and Preta $\left(r_{\text {Spearman }}=0.84\right)$,

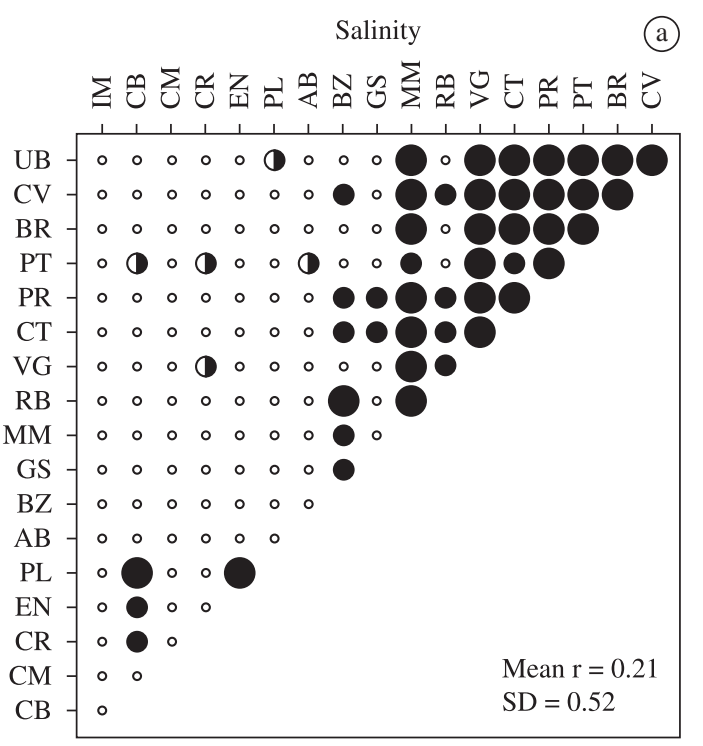

\section{Chlorophyll-a

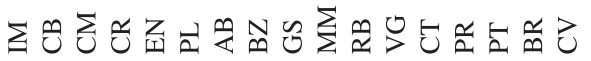

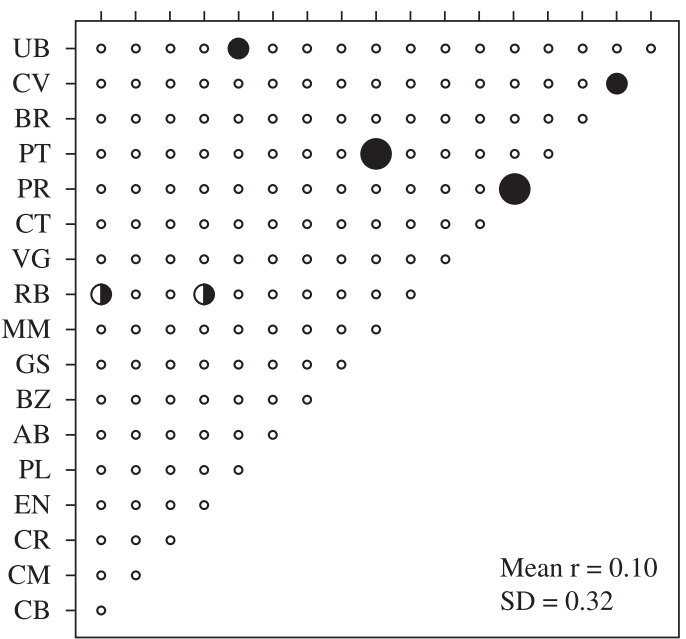

- Not significant Negative significant

- Significant $0.61 \leq r<0.8 \bigcirc$ Significant $r \geq 0.81$

Figure 2. Schematic representation of the results of the Spearman correlation values for salinity a) and for chlorophyll- $a$ b) between all pairs of lagoons (2004-2008 data-set). $\mathrm{IM}=$ Imboassica, $\mathrm{CB}=$ Cabiúnas, $\mathrm{CM}=$ Comprida, $\mathrm{CR}=$ Carapebus, $\mathrm{EN}=$ Encantada, $\mathrm{PL}=$ Paulista, $\mathrm{AB}=$ Amarra-Boi, $\mathrm{BZ}=$ Bezerra, $\mathrm{GS}=$ Garças, $\mathrm{MM}=$ Maria Menina, $\mathrm{RB}=$ Robalo, $\mathrm{VG}=$ Visgueiro, $\mathrm{CT}=$ Catingosa, $\mathrm{PR}=$ Pires, $\mathrm{PT}=$ Preta, $\mathrm{BR}=$ Barrinha, $\mathrm{CV}=$ Casa Velha, $\mathrm{UB}=$ Ubatuba.
Barrinha and Casa Velha $\left(r_{\text {Spearman }}=0.71\right)$ and Pires and Catingosa $\left(r_{\text {Spearman }}=0.88\right)$ (Figure $\left.2 \mathrm{~b}\right)$. On the other hand, the Chl- $a$ values for the Robalo lagoon were negatively related to those of Imboassica $\left(r_{\text {Spearman }}=-0.64\right)$ and Carapebus ( $\left.r_{\text {Spearman }}=-0.69\right)$ (Figure 2b). Overall, the mean $r_{\text {Spearman }}$ for Chl- $a$ for this data set was 0.10 ( $\mathrm{SD}=0.32$, Figure $2 \mathrm{~b}$ ).

Considering the monthly samplings in the Imboassica, Cabiúnas, Comprida, Carapebus and Garças lagoons, there was a strong correlation of water temperature $\left(r_{\text {Pearson }}>0.81\right)$ for all but one of the lagoon pairs (mean $r_{\text {Pearson }}=0.86$, $\mathrm{SD}=0.05$, Figure $4 \mathrm{a})$. Only the Imboassica-Garças pair presented a slightly weaker correlation $\left(r_{\text {Pearson }}=0.77\right.$, Figure 4a). The water colour in the Cabiúnas lagoon was positively correlated to the four other lagoons $\left(r_{\text {Pearson }}>0.41\right)$, and its strongest correlation was found with the Comprida lagoon $\left(r_{\text {Pearson }}=0.68\right)$ (Figure $\left.4 \mathrm{~b}\right)$. The water colour in the Comprida lagoon was also positively correlated to that of Carapebus $\left(r_{\text {Pearson }}=0.70\right)$ (Figure $\left.4 \mathrm{~b}\right)$. The mean correlation coefficient for the water colour was 0.39 ( $\mathrm{SD}=0.23$, Figure $4 \mathrm{~b}$ ). The degree of temporal coherence for the water colour between the lagoon pairs was negatively related to their difference in $\Delta$ perimeter:area ratio $\left(r^{2}=0.78\right.$, $\mathrm{p}=0.046$, Figure 5). For these 5 lagoons, water colour was generally higher in the summer months (rainy season), when compared to the other months of the year (Figure 6). Both the season (main independent variable, $\mathrm{F}=14.2483$, $\mathrm{p}=0.0014$ ) and the mean monthly precipitation (co-variable, $\mathrm{F}=14.2483, \mathrm{p}=0.0014)$ significantly affected the water colour in this group of lagoons (Table 3 ).

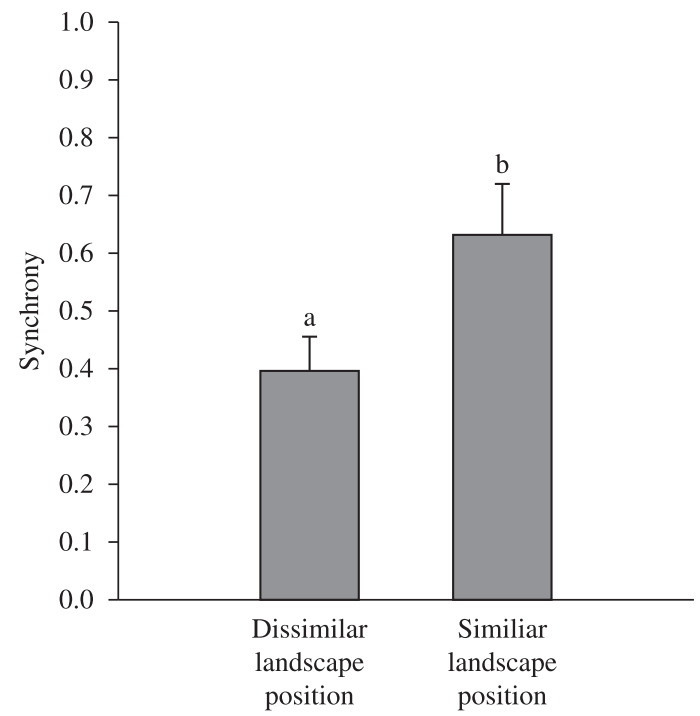

Figure 3. Temporal coherence expressed as the average correlation coefficients $\left(r_{\text {Spearman }}\right)$ between pairs of lagoons at similar [(parallel-oriented versus parallel-oriented) or (orthogonally-oriented versus orthogonally-oriented)] or dissimilar (parallel-oriented versus orthogonally-oriented) landscape positions. The different letters over the bars indicate a significant difference between the groups ( $t$-test, $\mathrm{p}<0.05)$. The error bars depict standard deviation. 
There was a positive correlation of the salinity for almost all of the pairs of lagoons (overall mean $r_{\text {Pearson }}=0.26$, $\mathrm{SD}=0.23$, Figure $4 \mathrm{c}$ ) after considering the monthly samplings. However, the salinity of the Carapebus lagoon had only a significant correlation with the Cabiúnas lagoon $\left(r_{\text {Pearson }}=0.49\right.$, Figure $\left.4 \mathrm{c}\right)$. Most of the significant correlations for the salinity within this dataset were $0.41<r_{\text {Pearson }}<0.60$, whereas the correlations of the salinity between Imboassica and Cabiúnas, Imboassica and Comprida, and Cabiúnas and Comprida were weaker $\left(0.21<r_{\text {Pearson }}<0.40\right)$ (Figure $4 \mathrm{c}$ ). The significant positive correlations for the Chl- $a$ values were only occasional and week $\left(0.21<r_{\text {Spearman }}<0.40\right)$ for the lagoons for this dataset

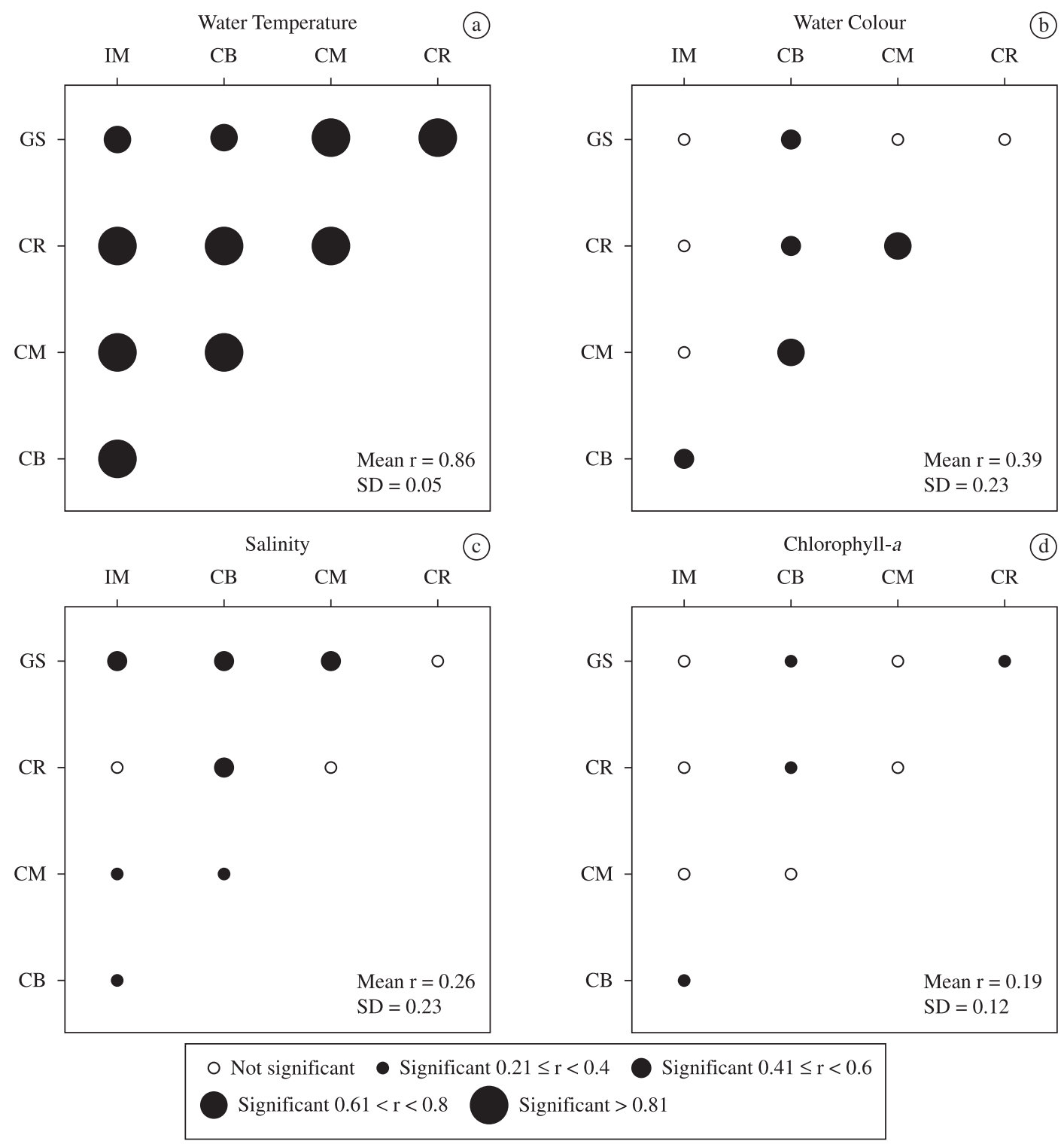

Figure 4. Schematic representation of the results of Pearson's correlation values for water temperature a), water colour b) and salinity c), and for Spearman correlations values for chlorophyll- $a$ d) between all pairs of the more extensively sampled 5 lagoons (2002-2008). IM = Imboassica, CB = Cabiúnas, $\mathrm{CM}=$ Comprida, $\mathrm{CR}=$ Carapebus, $\mathrm{GS}=\mathrm{Garças}$.
(Figure 4d). These positive correlations were found between Cabiúnas and Imboassica, Cabiúnas and Garças, Cabiúnas and Carapebus, and Carapebus and Garças (Figure 4d). Overall, the mean $r_{\text {Spearman }}$ for the Chl- $a$ for these lagoons was $0.19(\mathrm{SD}=0.12$, Figure $4 d)$.

\section{Discussion}

The coastal lagoons sampled here provide an ideal range of conditions to test the hypotheses of temporal coherence. All of the lagoons were exposed to the same climate, soil type and surrounding vegetation, but differed significantly in the morphometry, landscape position and trophic status.
○ Not significant $\bullet$ Significant $0.21 \leq \mathrm{r}<0.4$ 
Such conditions allowed us to comprehensively test whether or not coastal lagoons exhibit broad-scale similarities in the temporal trajectories of system variables, or if internal processes predominantly governed them. For individual variables, we observed that the coherent spatial patterns among the lakes were highly idiosyncratic regarding their magnitude of temporal variation. Considering the two data sets that were analysed, the physical variable (temperature) was more temporally coherent than the chemical variables (salinity and water colour), which in turn were more temporally coherent than the biotic variable (Chl-a). This result corroborates our first hypothesis and confirms that the temporal coherent behaviours among the lagoons are context-dependent on the identity of the

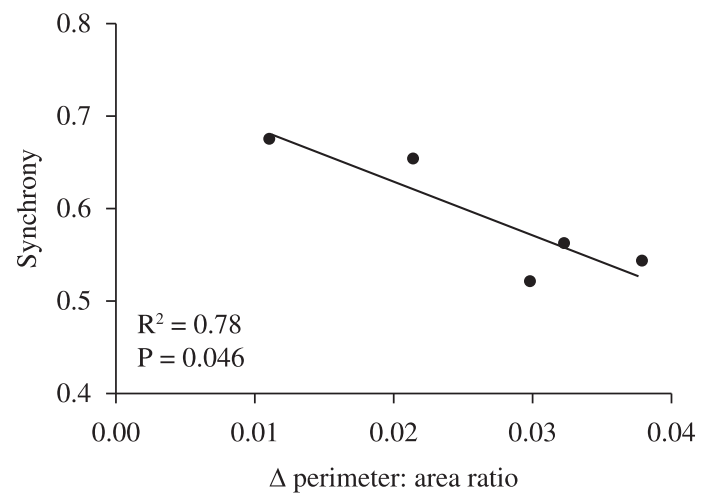

Figure 5. Significant pairwise correlations (positive Spearman correlation coefficients, $r$ ) of water colour for the more extensively sampled 5 lagoons (Imboassica, Cabiúnas, Comprida, Carapebus, Garças, 2002-2008) regressed as a function of the respective differences (i.e., distance) between their perimeter: area ratio.

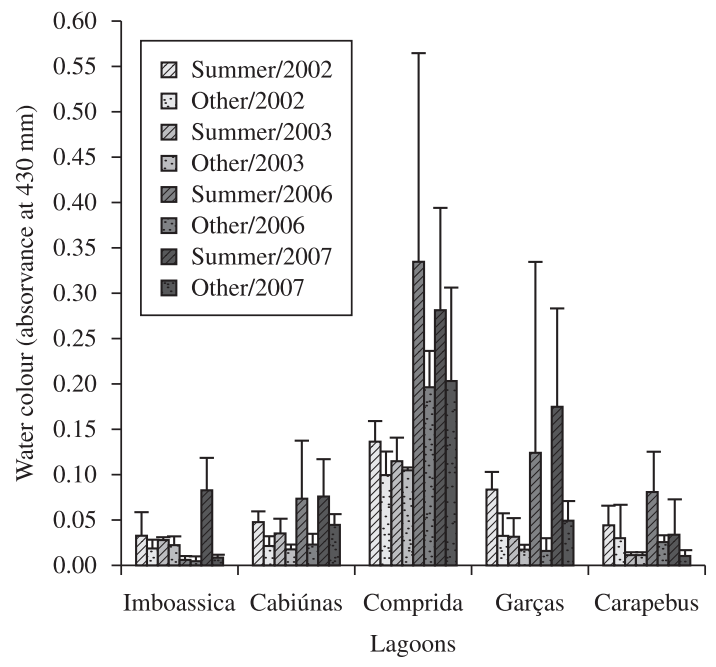

Figure 6. Mean water colour in the summer (December to February) versus other months of the year for Imboassica, Cabiúnas, Comprida, Garças and Carapebus lagoon (2002, 2003, 2006 and 2007). Error bars depict standard deviation. variable considered, a pattern that has been consistently shown for temperate lakes (Baines et al., 2000; Benson et al., 2000; Arnott et al., 2003). However, considering all of the variables, we observed a moderate to low temporal coherence among the tropical coastal lagoons (grand mean of the correlation coefficient $r \sim 0.33$ ). Finally, we observed that local factors, such as morphometry and landscape position of the lagoon, and regional factors, such as precipitation, were determinant mechanisms to explain part of the temporal coherent variation among the coastal lagoons. This result reaffirms that the landscape and lake-specific factors are both important and interact to govern the way aquatic systems are synchronous in their temporal trajectories.

The range of variables included in the study influences temporal coherence analyses. In our analyses, we selected a simple set of variables that encompass different functioning aspects of the lagoons, which are ultimately affected by their interaction with the atmosphere, the watershed and the ocean. The water temperature of the surface had the highest pattern of coherence, despite considerable differences among the lagoons in the concentration of the humic dissolved organic carbon (Figure 6). Humic substances might affect the thermal budget of the aquatic system by interfering with heat absorption (Steinberg et al., 2006). Therefore, large dissimilarities in the water colour among the lagoons would weaken or disrupt landscape coherent variation in water temperature. Our results indicate that there is an overwhelming control of the regional climate over the temporal trajectories in a lagoon's thermal balance, despite differences in such specific local conditions. Furthermore, we believe that the observed high temporal coherence in the water temperature among the coastal lagoons is likely related to a combination of the shallowness of the lagoons and their high exposition to wind. This interaction results in weak or absent thermal stratification, which in turn has been credited to affect coherent behaviour in the water temperature among temperate lakes (Baines et al., 2000). With very few exceptions, the water temperature has been shown to be highly coherent among temperate and arctic lakes (Baines et al., 2000; Benson et al., 2000; Arnott et al., 2003; Blenckner et al., 2007), and this pattern is related to a substantial seasonal thermal amplitude throughout the year. We expected that the temperature coherence would be weaker for tropical aquatic systems, where the seasonal

Table 3. Results for the mixed linear model testing the effects of the season and of the mean monthly precipitation on water colour for the data-set with 5 lagoons: Imboassica, Cabiúnas, Comprida, Carapebus and Garças. Significant $\mathrm{p}$ values $(\mathrm{p}<0.05)$.

\begin{tabular}{lrll}
\hline & d.f. & F-value & p-value \\
\hline Intercept & 1,18 & 5.6702 & 0.0285 \\
Season & 1,18 & 6.8654 & 0.0173 \\
Mean monthly & 1,18 & 14.2384 & 0.0014 \\
precipitation & & & \\
\hline
\end{tabular}


thermal amplitude is lower. Our results, combined with those in the literature for temperate systems, corroborate recent expectations that lake ecosystems are strong sentinels and integrators of global climate change over larger spatial and temporal scales (Schindler, 2009).

Our study demonstrates that the landscape position and morphometry of the lagoons were important predictors of the temporal coherent behaviour of the salinity and water colour. Previous studies have already emphasised the importance of landscape position on temporal coherence among lake ecosystems for a myriad of chemical variables (Kratz et al., 1997; Kratz and Frost, 2000; Webster et al., 2000). However, our study is the first to show how similarities in the geographic orientation of water bodies relative to the sea affect broad-scale synchrony in the salinity among the lagoons. Particularly, we found that lagoons that are similar in their relative position to the sea (i.e., both paralleloriented or both orthogonally-oriented) show significantly more temporal coherent variation in the water salinity than the average of correlations that were calculated between parallel-oriented vs. orthogonally-oriented lagoons. The parallel-oriented lagoons have a greater proportion of their perimeter closer to the sea than the orthogonally-oriented lagoons, which facilitates salt water intrusion by waves breaking over the top of the sand barrier during sea storm events (Kjerfve, 1994). In addition, parallel-oriented coastal lagoons might also be more prone to saltwater spray deposition. On the other hand, variations in the salinity are strongly related to freshwater inputs from their catchment area in the orthogonally-oriented lagoons. Temporal coherence in the salinity among coastal lagoons has important ecological consequences regarding our ability to predict how future scenarios of rising sea levels that have originated from climate change might affect broad-scale salinisation patterns of coastal inland aquatic systems, a phenomenon that purportedly has pronounced effects on the community structure and functioning of resident biota of the coastal lagoons (Caliman et al., 2007; Santangelo et al., 2007; Bozelli et al., 2009; Laque et al., 2010). Despite the considerations mentioned above, the salinity coherence was somewhat low, with more than half of the total number of correlations showing non-significant results. This result suggests that other local characteristics of coastal lagoons related to the salt and freshwater balance, such as the catchment area, volume and sand barrier height (which might affect sea water intrusion), are likely to weaken the temporal coherence among lagoons.

We used water colour as a proxy of humic dissolved organic carbon (Pace and Cole, 2002), which is mainly derived from the terrestrial organic components that move into the coastal lagoons (Suhett et al., 2007; Farjalla et al., 2009). Humic substances have multiple effects on the physical, chemical and biological processes that occur in lakes. For instance, humic substances attenuate solar radiation by affecting the thermal balance of aquatic ecosystems and reducing the damage of UV radiation on phytoplankton and zooplankton organisms (Steinberg et al., 2006). There are many local and regional factors that regulate the concentration and composition of humic substances in lakes, but most of the factors are related to the morphometry and the characteristics of the catchment area of the lake (reviewed in Zhang et al., 2010). In our study, the ratio between the perimeter and area of the lagoon and the regional precipitation were both important aspects needed to delineate the patterns of temporal coherence in water colour between the lagoons. Temporal coherence was higher among lagoons that shared similar morphometric characteristics, which in turn gives a reasonable proxy for land-water connectivity for aquatic systems that do not vary widely in depth (Hakanson, 2004). Precipitation regulates the input of allochthonous humic carbon for the coastal lagoons studied (Suhett et al., 2007). In fact, we observed a clear seasonal pattern of the water colour variation among the coastal lagoons (Figure 6), suggesting that regional climate is important for determining spatial patterns of temporal coherence among the systems. In a pragmatic point of view, this information gives us an opportunity to predict how alterations in the catchment area of a lagoon, by deforestation, for instance, will propagate modifications in the input of terrestrial subsidies across the landscape.

Previous studies have shown that temporal coherence in biotic variables tends to be lower than in physical and chemical variables, and even absent in some cases (e.g., Magnuson et al., 1990; Kratz et al., 1997; Baines et al., 2000; Livingstone and Dokulil, 2001; but see Kent et al., 2007; Lansac-Toha et al., 2008; Rusak et al., 1999 for the contrary). In general, it is expected that biological variables have low levels of temporal coherence among systems because they are influenced by a combination of mechanisms that include species-specific growth rates, species-specific tolerances to stressors, nutrient dynamics, predation pressure, and other food web dynamics (Arnott et al., 2003). In our study, we observed a generally weak coherence of the Chl- $a$ among the coastal lagoons $(\mathrm{r}<0.2)$, and we suggest that a variation in the composition of aquatic species (de Mello and Suzuki, 1998; Castelo-Branco 1998; Caramaschi et al., 2004), a summation of physiographic (Panosso et al., 1998) and trophic state differences among the lagoons, explain this pattern.

There are intriguing differences in the frequency of the Chl- $a$ temporal coherence between the two data sets analysed. Only four out of 153 possible correlations were positive and significant for the data set comprising 18 semi-annually sampled lagoons, while four out of 10 possible correlations were positive and significant for the data set comprising the five monthly-sampled lagoons. We expected that the great number of individual observations related to monthly samplings would increase the power of the analysis, and that semi-annual samplings would highlight the importance of climatic control on the system variables, thereby enhancing the likelihood for the detection of temporal coherence (Folster et al., 2005; George et al., 2000). We suggest that the unexpected lower frequency of coherence of the Chl- $a$ in the data set comprised for the 18 lagoons is related to the higher regional heterogeneity in an analysis that included all of the lagoons. 
Our study demonstrates the patterns and potential mechanisms regarding temporal coherence in a suite of system variables across tropical coastal lagoons. Further investigation is required to determine the extent to which these results are consistent over larger spatial and temporal scales, as well as to determine whether the results apply to other important system variables such as species composition. Overall, our results are within the range of the observed patterns of temporal coherence registered for temperate lakes, and highlight a potential generality of the synchronous behaviour of the landscape in system variables in different global climates and across physiographically diversified systems. The degree to which temporal coherence might be an important tool for the prediction and extrapolation of landscape patterns from a suite of lakes is seemingly dependent on the considered variable. We stress that there is a need to reanalyse the large amount of existing data that monitors the tropical aquatic systems into the context of temporal coherence. These efforts will expand our understanding of whether local characteristics, regional environmental drivers or both determine, more consistently, the dynamics of an aquatic ecosystem and how this regulation occurs.

Acknowledgements - The authors are grateful to past and current students of the Limnology Laboratory of the Universidade Federal do Rio de Janeiro who sampled the data that was analysed in this study for almost two decades. We are also indebted to the staff of the Núcleo de Desenvolvimento Sócio-Ambiental de Macaé (NUPEM/UFRJ) and to Instituto Chico Mendes for logistical assistantship and permission for sampling the lagoons at the Restinga de Jurubatiba National Park, respectively. This work was financed by PETROBRAS and by the Conselho Nacional de Desenvolvimento Científico e Tecnológico (CNPq) in the context of the Brazilian Long-Term Ecological Research Program (PELD, site-5). Scholarships were provided by the Coordenadoria de Pessoal de Nível Superior" (CAPES), "Fundação de Amparo a Pesquisa do Estado do Rio de Janeiro" (FAPERJ) and CNPq.

\section{References}

ARNOTT, SE., KELLER, B., DILLON, PJ., YAN, N., PATERSON, M. and FINDLAY, D., 2003. Using temporal coherence to determine the response to climate change in boreal shield lakes. Environmental Monitoring and Assessment, vol. 88, no. 1-3, p. 365-388.]

BAINES, SB., WEBSTER, KE., KRATZ, TK., CARPENTER, SR. and MAGNUSON, JJ., 2000. Synchronous behavior of temperature, calcium, and chlorophyll in lakes of northern Wisconsin. Ecology, vol. 81, no. 3, p. 815-825.

BENSON, BJ., LENTERS, JD., MAGNUSON, JJ., STUBBS, M., KRATZ, TK., DILLON, PJ., HECKY, RE. and LATHROP, RC., 2000. Regional coherence of climatic and lake thermal variables of four lake districts in the Upper Great Lakes Region of North America. Freshwater Biology, vol. 43, no. 3, p. 517-527.

BERG, A., ORTHEN, B., MATTOS, EA., DUARTE, HM. and LÜTTGE, U., 2004. Expression of crassulacean acid metabolism in Clusia hilariana Schlechtendal in different stages of development in the field. Trees, vol. 18, no. 5, p. 553-558.
BLENCKNER, T., ADRIAN, R., LIVINGSTONE, DM., JENNINGS, E., WEYHENMEYER, GA., GEORGE, DG., JANKOWSKI, T., JARVINEN, M., AONGHUSA, CN., NOGES, T., STRAILE, D. and TEUBNER, K., 2007. Large-scale climatic signatures in lakes across Europe: a meta-analysis. Global Change Biology, vol. 13, no. 7, p. 1314-1326.

BOZELLI, RL., CALIMAN, A., GUARIENTO, RD., CARNEIRO, LS., SANTANGELO, JM., FIGUEIREDO-BARROS, MP., LEAL, JJF., ROCHA, AM., QUESADO, LB., LOPES, PM., FARJALLA, VF., MARINHO, CC., ROLAND, F. and ESTEVES, FA., 2009. Interactive effects of environmental variability and human impacts on the long-term dynamics of an Amazonian floodplain lake and a South Atlantic coastal lagoon. Limnologica, vol. 39, no. 4, p. 306-313.

CALIMAN, A., LEAL, JJF., ESTEVES, FA., CARNEIRO, LS., BOZELLI, RL., and FARJALLA, VF., 2007. Functional bioturbator diversity enhances benthic-pelagic processes and properties in experimental microcosms. Journal of North American Benthological Society, vol. 26, no. 3, p. 450-459.

CARAMASCHI, EP., SÁNCHEZ-BOTERO, JI., HOLLANDACARVALHO, P., BRANDÃO, CAS., SOARES, CL., NOVAES, JLC. and BARTOLETTE, R., 2004. Peixes das lagoas costeiras do norte fluminense: estudo de caso. In ROCHA, CFD., ESTEVES, FA. and SCARANO, FR. Pesquisas de longa duração na Restinga de Jurubatiba: ecologia, história natural e conservação. Rio de Janeiro: Rima. p. 376.

CARPENTER, SR., BENSON, BJ., BIGGS, R., CHIPMAN, JW., FOLEY, JA., GOLDING, SA., HAMMER, RB., HANSON, PC., JOHNSON, PTJ., KAMARAINEN, AM., KRATZ, TK., LATHROP, RC., MCMAHON, KD., PROVENCHER, B., RUSAK, JA., SOLOMON, CT., STANLEY, EH., TURNER, MG., VANDER ZANDEN, MJ., WU, CH. and YUAN, HL., 2007. Understanding regional change: a comparison of two lake districts. Bioscience, vol. 57 , no. 4, p. 323-335.

CASTELO-BRANCO, CW., 1998. Composição e aspectos ecológicos das comunidades zooplanctônicas nas lagoas Imboassica, Cabiúnas e Comprida. In ESTEVES, FA. Ecologia das Lagoas Costeiras do Parque Nacional da Restinga de Jurubatiba e do Município de Macaé (RJ). Rio de Janeiro: Nupem/UFRJ. p. 464

DAS, B., NARWANI, A., MATTHEWS, B., NORDIN, R. and MAZUMDER, A., 2009. Anthropogenic disturbance history influences the temporal coherence of paleoproductivity in two lakes. Journal of Paleolimnology, vol. 42, no. 2, p. 167-181.

ENRICH-PRAST, A., BOZELLI, RL., ESTEVES, FA. and MEIRELLES, FP., 2004. Lagoas costeiras da restinga de jurubatiba: descrição de suas variáveis limnológicas. In ROCHA, CFD., ESTEVES, FA. and SCARANO, FR. Pesquisas de longa duração na Restinga de Jurubatiba: ecologia, história natural e conservação. Rio de Janeiro: Rima. p. 376.

ESTEVES, FA., CALIMAN, A., SANTANGELO, JM., GUARIENTO, RD., FARJALLA, VF. and BOZELLI, RL., 2008. Neotropical coastal lagoons: an appraisal of their biodiversity, functioning, threats and conservation management. Brazilian Journal of Biolology, vol. 68, no. 4, p. 967-981.

FARJALLA, VF., AMADO, AM., SUHETT, AL. and MEIRELLESPEREIRA, F., 2009. DOC removal paradigms in highly humic aquatic ecosystems. Environmental Science \& Pollution Research, vol. 16 , no. 5 , p. 531-538. 
FARJALLA, VF., FARIA, BM. and ESTEVES, FA., 2002. The relationship between DOC and planktonic bacteria in tropical coastal lagoons. Archiv für Hydrobiologie, vol. 156, no. 1, p. 97-119.

FOLSTER, J., GORANSSON, E., JOHANSSON, K. and WILANDER, A. 2005. Synchronous variation in water chemistry for 80 lakes in southern Sweden. Environmental Monitoring and Assessment, vol. 102, no. 1-3, p. 389-403.

GEORGE, DG., TALLING, JF. and RIGG, E., 2000. Factors influencing the temporal coherence of five lakes in the English Lake District. Freshwater Biology, vol. 43, no. 3, p. 449-461.

HAKANSON, L., 2004. Lakes: form and function. Caldwell: The Blackburn Press.

KENT, AD., YANNARELL, AC., RUSAK, JA., TRIPLETT, EW. and McMAHON, KD., 2007. Synchrony in aquatic microbial community dynamics. Isme Journal, vol. 1, no. 1, p. 38-47.

KJERFVE, B., 1994. Coastal lagoon processes. In KJERFVE, B. Coastal lagoon processes. New York: Elsevier. p. 1-8.

KRATZ, TK. and FROST, TM., 2000. The ecological organisation of lake districts: general introduction. Freshwater Biology, vol. 43, no. 3, p. 297-299.

KRATZ, TK., BENSON, BJ., BLOOD, ER., CUNNINGHAM, GL. and DAHLGREN, RA., 1991. The influence of landscape position on temporal variability in 4 north-american ecosystems. The American Naturalist, vol. 138, no. 2, p. 355-378.

KRATZ, TK., DEEGAN, LA., HARMON, ME. and LAUENROTH, WK., 2003. Ecological variability in space and time: Insights gained from the US LTER program. Bioscience, vol. 53, no. 1, p. 57-67.

KRATZ, TK., WEBSTER, KE., BOWSER, CJ., MAGNUSON, JJ. and BENSON, BJ., 1997. The influence of landscape position on lakes in northern Wisconsin. Freshwater Biology, vol. 37, no. 1, p. 209-217.

LANSAC-TOHA, FA., BINI, LM., VELHO, LFM., BONECKER, CC., TAKAHASHI, EM. and VIEIRA, LCG., 2008. Temporal coherence of zooplankton abundance in a tropical reservoir. Hydrobiologia, vol. 614, no. 1, p. 387-399.

LAQUE, T., FARJALLA, VF., ROSADO, AS. and ESTEVES, FA. 2010. Spatiotemporal variation of bacterial community composition and possible controlling factors in tropical shallow lagoons. Microbial Ecology, vol. 59, no. 4, p. 819-829.

LIVINGSTONE, DM. and DOKULIL, MT., 2001. Eighty years of spatially coherent Austrian lake surface temperatures and their relationship to regional air temperature and the North Atlantic Oscillation. Limnology Oceanography, vol. 46, no. 5, p. $1220-1227$.

MAGNUSON, JJ., BENSON, BJ. and KRATZ, TK., 1990. Temporal coherence in the limnology of a suite of lakes in wisconsin, USA. Freshwater Biology, vol. 23, no. 1, p. 145-159.

MELLO, S. de and SUZUKI, MS., 1998. Variações temporais e espaciais do fitoplâncton das lagoas Imboassica, Cabiúnas e Comprida. In ESTEVES, FA. Ecologia das Lagoas Costeiras do Parque Nacional da Restinga de Jurubatiba e do Município de Macaé (RJ). Rio de Janeiro: Nupem/UFRJ. p. 464.

NUSH, EA. and PALME, G., 1975. Biologische methoden fur die Praxis der Gewasseruntersushung. GWF und Wasser/Abwasser, vol. 116, p. 562-565.
PACE, ML. and COLE, JJ., 2002. Synchronous variation of dissolved organic carbon and color in lakes. Limnology Oceanography, vol. 47, no. 2, p. 333-342.

PANOSSO, RF., ATTAYDE, JL. and MUEHE, D. 1998. Morfometria das lagoas Imboassica, Cabiúnas, Comprida e Carapebus: implicações para seu funcionamento e manejo. In ESTEVES, FA. Ecologia das Lagoas Costeiras do Parque Nacional da Restinga de Jurubatiba e do Município de Macaé (RJ). Rio de Janeiro: Nupem/UFRJ. p. 464.

R Development Core Team, 2009. $R$ : a language and environment for statistical computing. Version 2.8.0. Vienna: R Foundation for Statistical Computing.

ROCHA, AM., SANTANGELO, JM., BRANCO, CWC. and CARNEIRO, LS., 2004. Dinâmica temporal de longa duração e os efeitos de distúrbios antrópicos na comunidade zooplanctônica da lagoa Imboassica, Macaé, RJ. In ROCHA, CFD., ESTEVES, FA. and SCARANO, FR. Pesquisas de longa duração na restinga de Jurubatiba: ecologia, história natural e conservação. São Carlos: Rima. p. 376.

ROCHA, CFD., ESTEVES, FA. and SCARANO, FR., 2004. Pesquisas de longa duração na Restinga de Jurubatiba: ecologia, história natural e conservação. Rio de Janeiro: RiMa.

RUSAK, JA., YAN, ND., SOMERS, KM. and McQUEEN, DJ., 1999. The temporal coherence of zooplankton population abundances in neighboring north-temperate lakes. The American Naturalist, vol. 153, no. 1, p. 46-58.

SANTANGELO, JM., ROCHA, ADM., BOZELLI, RL., CARNEIRO, LS. and ESTEVES, FDA. 2007. Zooplankton responses to sandbar opening in a tropical eutrophic coastal lagoon. Estuarine, Coastal and Shelf Science, vol. 71, no. 3-4, p. 657-668.

SCHINDLER, DW. 2009. Lakes as sentinels and integrators for the effects of climate change on watersheds, airsheds, and landscapes. Limnology Oceanography, vol. 54, no. 6, p. 2349-2358.

SORANNO, PA., WEBSTER, KE., RIERA, JL., KRATZ, TK., BARON, JS., BUKAVECKAS, PA., KLING, GW., WHITE, DS., CAINE, N., LATHROP, RC., and LEAVITT, PR., 1999. Spatial variation among lakes within landscapes: ecological organization along lake chains. Ecosystems, vol. 2, no. 5, p. 395-410.

STEINBERG, CEW., KAMARA, S., PROKHOTSKAYA, VY., MANUSADZIANAS, L., KARASYOVA, TA., TIMOFEYEV, MA., JIE, Z., PAUL, A., MEINELT, T., FARJALLA, VF., MATSUO, AYO., BURNISON, BK. and MENZEL, R., 2006. Dissolved humic substances - ecological driving forces from the individual to the ecosystem level? Freshwater Biology, vol. 51, no. 7, p. 1189-1210.

STODDARD, JL., DRISCOLL, CT., KAHL, JS. and KELLOGG, JP., 1998. Can site-specific trends be extrapolated to a region? An acidification example for the northeast. Ecological Applications, vol. 8, no. 2, p. 288-299.

STROME, DJ. and MILLER, MC., 1978. Photolytic changes in dissolved humic substances. Verhandlungen Internationale Vereinigung für Theoretische und Angewandte Limnologie, vol. 20, p. 1248-1254.

SUHETT, AL., AMADO, AM., ENRICH-PRAST, A., ESTEVES, F. de A. and FARJALLA, VF., 2007. Seasonal changes of dissolved organic carbon photo-oxidation rates in a tropical humic lagoon: the role of rainfall as a major regulator. Canadian Journal of Fisheries and Aquatic Sciences, vol. 64, no. 9, p. 1266-1272. 
TAKAHASHI, EM., LANSAC-TOHA, FA., VELHO, LFM. and BINI, LM. 2008. The temporal asynchrony of planktonic cladocerans population at different environments of the Upper Parana River floodplain. Int. Rev. Hydrobiol., vol. 93, no. 6, p. 679-689.

WEBSTER, KE., SORANNO, PA., BAINES, SB., KRATZ, TK., BOWSER, CJ., DILLON, PJ., CAMPBELL, P., FEE, EJ. and HECKY, RE., 2000. Structuring features of lake districts: landscape controls on lake chemical responses to drought. Fresh. Biol., vol. 43, no. 3, p. 499-515.
WEYHENMEYER, GA., 2008. Rates of change in physical and chemical lake variables: are they comparable between large and small lakes? Hydrobiologia, vol. 599, no. p. 105-110.

ZHANG, J., HUDSON, J., NEAL, R., SEREDA, J., CLAIR, T., TURNER, M., JEFFRIES, D., DILLON, P., MOLOT, L., SOMERS, K. and HESSLEIN, R., 2010. Long-term patterns of dissolved organic carbon in lakes across eastern Canada: evidence of a pronounced climate effect. Limnol. Oceanogr, vol. 55 , no. 1 , p. 30-42. 